2014-01-01

\title{
Molluscs from a shallow-water whale-fall and their affinities with adjacent benthic communities on the Swedish west coast
}

\section{Danise, S}

http://hdl.handle.net/10026.1/3333

\subsection{0/17451000.2013.793811 \\ Marine Biology Research}

All content in PEARL is protected by copyright law. Author manuscripts are made available in accordance with publisher policies. Please cite only the published version using the details provided on the item record or document. In the absence of an open licence (e.g. Creative Commons), permissions for further reuse of content should be sought from the publisher or author. 


\section{Molluscs from a shallow-water whale-fall in the North Atlantic}

2 Danise Silvia $^{1,2^{*}}$, Stefano Dominici ${ }^{3}$, Thomas G. Dahlgren ${ }^{4,5}$ and Adrian G. Glover ${ }^{6}$

$3 \quad{ }^{1}$ Dipartimento di Scienze della Terra, Università di Firenze, 50121, Firenze, Italy.

$4 \quad{ }^{2}$ Present address: School of Geography, Earth and Environmental Sciences, University of

5 Plymouth, Drake Circus, Plymouth, Devon, PL4 8AA, UK.

$6{ }^{3}$ Museo di Storia Naturale, Sezione di Geologia e Paleontologia, Università di Firenze, 7 50121, Firenze, Italy.

$8{ }^{4}$ Present address: Uni Research/Uni Environment, N-5020 Bergen, Norway.

$9 \quad{ }^{5}$ Department of Zoology, Göteborg University, 40530 Göteborg, Sweden.

$10{ }^{6}$ Zoology Department, The Natural History Museum, London, SW7 5BD, United Kindom.

11 *email: silvia.danise@plymouth.ac.uk

13 Running head: Molluscs from a shallow whale-fall

14 Key words: whale fall, Bivalvia, chemosynthetic, Thyasira sarsi, North Atlantic, organic15 enriched sediments, minke whale

17 ABSTRACT: We conducted a species-level study of molluscs associated with a $5 \mathrm{~m}$ long carcass of a minke whale at a depth of $125 \mathrm{~m}$ in the Kosterfjord (North Sea, Sweden). The whale fall community was quantitatively compared with the community commonly living in the surrounding soft-bottom sediments. Five years after the deployment of the dead whale at the sea floor, the sediments around the whale carcass were dominated by the bivalve Thyasira sarsi (Philippi), which is known to contain endosymbiotic sulphur-oxidizing bacteria, whilst

23 the background sediments were dominated by another thyasirid, T. equalis (Verril \& Bush), less dependent on chemosynthesis for its nutrition. The Kosterfjord samples were further compared at the species level with mollusc abundance data derived from the literature and including samples from different marine settings of the west coast of Sweden (active methane

27 seep, fjords, coastal and open marine environments). The results show high similarity 
between the Kosterfjord whale-fall community and the community developed in one of the Swedish fjords (Gullmar Fjord) during hypoxic conditions. This study indicates that at shallow-water whale falls, the sulphophilic stage of the ecological succession is characterized by generalist chemosynthetic bivalves commonly living in organic-rich, sulphidic environments.

\section{INTRODUCTION}

In the deep sea, the arrival of a whale carcass generates an organic-rich "island" in an otherwise food-poor deep-sea, supporting a highly specialized and diverse assemblage of animals that exhibit a series of successional stages (Smith \& Baco 2003). Sharks, hagfish and other scavenging organisms remove flesh and soft tissues (the mobile scavenger stage), polychaetes, crustaceans and other opportunistic small-sized animals thrive on organic remains (the enrichment opportunist stage), whilst a long-lasting and complex community relies on the hydrogen sulphide and other chemical compounds produced by microbial consumption of the lipid-rich bones (the sulphophilic stage: Smith \& Baco 2003). During the sulphophilic stage chemosynthetic bacteria - free living or in symbiosis within vesicomyid clams, bathymodiolin mussels and siboglinid tube worms - are at the base of a food web where organic matter is primarily produced by the oxidation of inorganic compounds. Some of these animals are restricted to vertebrate carcasses, such as the gutless (although heterotrophic) bone-eating worm Osedax (Rouse et al. 2004, 2011), whilst chemosynthetic taxa are often found at other deep-sea reducing habitats, including hydrothermal vents and hydrocarbon seeps (Smith \& Baco 2003, Dubilier et al. 2008).

As they are not restricted to a specific geological setting, whale falls may have played a keyrole in the dispersal of chemosynthetic fauna among these habitats (the stepping stone hypothesis: Smith et al. 1989). Evidence consistent with this hypothesis includes molecular studies suggesting that some obligate taxa, specialist at deep-water extreme habitats, originated from shallow-water ancestors living on organic falls (Distel et al. 2000, Jones et al. 2006, Duperron 2010). However, natural whale falls from shallow waters, commonly defined as less than $200 \mathrm{~m}$ deep (see Dubilier et al. 2008, Dando 2010), are poorly documented in modern settings (see Smith 2006), and their faunal composition as well as the course of the ecological succession poorly known. The shelf-depth sea floor has much higher organic carbon content and hence the organic input from a whale carcass may represent a less significant contribution to nutrient budgets in comparison with the deep sea (Smith 2006). 
60

The only report of a fully developed natural (i.e not artificially sunk) whale-fall community in shallow waters comes from the fossil record, where the discovery of a late Pliocene (about $3 \mathrm{Ma}$ old) baleen-whale with large lucinid clams testifying for the sulphophilic stage, gave some insights with regard ecological succession at shelf depths (Dominici et al. 2009, Danise et a. 2010).

As natural whale falls are rarely encountered on the sea floor, the artificial sinking of whale carcasses and the subsequent monitoring of ecological succession is an extremely useful tool to analyse how community structure changes over time and to understand the relationships with other shallow and deep-water reducing environments. Time-series studies carried out so far on modern shallow-water whale falls in the North Sea show the presence on the shelf of some obligate taxa, such as the siboglinid Osedax mucofloris (Glover et al. 2005, Dahlgren et al. 2006). Several species of dorvilleid and chrysopetalid polychaetes documented at shallow whale falls are also present at other shallow sites characterized by high levels of organic carbon flux, such as fish farms (Dahlgren et al. 2004, Wiklund et al. 2009a, 2009b).

Studies of temporal processes at very shallow $(<40 \mathrm{~m})$ whale falls in the Gullmar Fjord, Sweden, show that decomposition of small cetacean carcasses at shelf-depth settings is initially considerably slower than at deep-sea sites, and that the carcasses are consumed by generalist mobile scavengers already known from the same area (Glover et al. 2010). The monitoring of a minke whale sunken at $30 \mathrm{~m}$ depth in the Sea of Japan reports the exclusive presence of non-selective deposit feeders associated with the carcass (Pavlyuk et al. 2009). With regard to molluscs, time-series studies have not yet been conducted in shallow waters, although isolated reports indicate the presence of the bathymodiolin mussel Idas simpsoni at 0-300 m depth in the North Sea living attached to whale bones (Marshall 1900, Tebble 1966, Warén 1991). Artificial whale falls sunk just below the $200 \mathrm{~m}$ depth threshold in the northwest Pacific (219-254 m: Fujiwara et al. 2007) show a general composition of the fauna similar to that of deep-water reducing habitats, with a chemosynthesis-based fauna mainly represented by the bathymodiolin mussel Adipicola pacifica. In contrast to this finding no evidence for a sulphophilic stage was found at a whale carcass artificially sunk at $385 \mathrm{~m}$ depth in the Monterey Submarine Canyon, north-eastern Pacific (Braby et al. 2007).

Here we present a species-level study of molluscs associated with a $5 \mathrm{~m}$ long minke whale (Balaenoptera acutorostrata) experimentally implanted in October 2003 at a depth of $125 \mathrm{~m}$ in the Kosterfjord (Skagerrak, Sweden). Time-series studies previously carried out on the 
same site have shown that the Atlantic hagfish (Myxine glutinosa), sharks and other scavenging organisms consumed the flesh and exposed the bones within 5 weeks of implantation, and that the carcass was completely skeletonised after 6 months on the sea floor (Dahlgren et al. 2006). Nine months after sinking the carcass was colonized by Osedax mucofloris, the first species of Osedax known from a shelf-depth whale-fall, and the first from the Atlantic Ocean (Glover et al. 2005, Dahlgren et al. 2006). Our sampling was performed 5 years after the sinking of the carcass. Sediment samples were collected at the whale fall sites and at the surrounding soft bottom sediments in order to compare the whale fall mollusc fauna with the organisms commonly living in the area. Our primary objective was to analyse the community structure of the benthic mollusc fauna associated with a shallow-water whale-fall. Our second aim was to evaluate the differences in taxonomic composition and community structure between the whale fall community, the surrounding background community and the macrofaunal community related to other ephemeral, sulphide-rich habitat of the same area. For this reason the Kosterfjord samples were merged into a larger dataset built from literature data on mollusc relative abundances at a regional scale. The set includes data from one large pockmark in the North Sea (150-168 m: Dando et al. 1991), from soft sediment samples collected in the Gullmar Fjord at $115 \mathrm{~m}$ depth at times of hypoxic bottom water conditions (Josefson 1986, 1987, 1988), and from soft sediment samples of the west coast of Sweden (21-106 m: Agrenius 2001, 2002, 2003, 2005).

\section{STUDY AREA}

The Kosterfjord is situated in the north eastern part of the Skagerrak, the major gateway between the north Atlantic and the Baltic Sea. It is a $250 \mathrm{~m}$ deep, $62 \mathrm{~km}$ long submarine trench parallel to the coastline of Sweden to the east and sheltered by the Koster islands to the west (Figure 1). The trench is a fault fissure connected in the north-west to the Norwegian Trough which in turn is connected to the deep North Atlantic. As a consequence of its connection with the North Atlantic and the prevailing open-ocean marine conditions (including high salinity) the Kosterfjord is not a typical fjord (Palm et al. 2004).

The Skagerrak bottom is characterized by muddy sediments and a high content of organic material (about $2 \%$ of organic carbon), with sedimentation rates of $0.20 \mathrm{~cm} / \mathrm{year}$ in the Northern sector (Josefson 1985, Van Weering et al. 1987). The overall oceanographic regime is driven by a counter clockwise circulation pattern, where dense, saline (30-35 psu) and oxygenated oceanic water underflows the more brackish $(8-30 \mathrm{psu})$ surface water outflow of 
124 the Baltic Sea. The main surface currents entering the area are the Jutland Current from the

125 North Sea (south-west) and the Baltic Current from south-east. The mixing between these

126 two currents forms the Norwegian Coastal Current, with a predominating northern heading,

127 which flows out of the Skagerrak on the Norwegian side. This surface circulation is

128 compensated by a deep counter current that brings the saline Atlantic water through the 700

129 m deep Norwegian Trench into the Skagerrak (Wisshak et al. 2005). However, the

130 temperature and salinity of the surface waters are subject to strong seasonal fluctuations; in

131 deeper waters the fluctuation is present with lower amplitude. Measurements of bottom water 132 temperature at $125 \mathrm{~m}$ depth in the Kosterfjord indicate only small variations during the year 133 of $4.8-7.5^{\circ} \mathrm{C}$, with salinity $34.3-34.7$ psu (Dahlgren pers. obs.).

134 The Gullmar Fjord is a $27 \mathrm{~km}$ long fjord on the west coast of Sweden, about 70km south of the Kosterfjord. It has a sill at $42 \mathrm{~m}$ water depth which restricts water flow to the deep basin of $115 \mathrm{~m}$ water depth. Periodically the water in the bottom of the basin has low oxygen

137 levels. During the 1979-1980 winter the bottom of the basin became azoic, due to oxygen 138 deficiency (Josefson \& Widbom 1988).

MATERIALS AND METHODS

140 Sampling. For the present study four sediment samples were collected and analysed for their 141 mollusc composition. Sample W1 was collected in May 2008 from the minke whale skeleton 142 at $125 \mathrm{~m}$ depth, samples B1, B2 and B3 (background samples) were collected in January 1432009 at a distance from whale bones, respectively $18 \mathrm{~m}$ south, 13 and $55 \mathrm{~m}$ north from the 144 whale, at 125-126 m depth. The sampling at the whale fall was conducted with a small 145 Speere ROV (Remotely Operated Vehicle) equipped with a forward-mounted sampling scoop $14616 \mathrm{~cm}$ long with a diameter of $8,4 \mathrm{~cm} .4420 \mathrm{~cm}^{3}$ of sediments were collected with three ROV 147 scoops close to the whale bones (W1), stored in a sample basket (size $34 \times 26.5 \times 25 \mathrm{~cm}$ ) and 148 retrieved. Due to its size and shape the scoop was able to collect only surface sediments (max 149 sampled depth $\sim 5 \mathrm{~cm})$. Each of the three background sediment samples (B1, B2, B3) was collected using a Van Veen grab with a sampling area of $0.1 \mathrm{~m}^{2}$ and that would have penetrated to on average of $7-10 \mathrm{~cm}$, and up to a maximum of $20 \mathrm{~cm}$. The total volume of collected sediments was about $15000 \mathrm{~cm}^{3}$ for each background sample (Table 1).

153 The sediment samples were wet sieved through a $0.5 \mathrm{~mm}$ screen and preserved in ethanol $154(\approx 80 \%)$ before identification. No attempt was made to separate live from dead individuals.

155 The residue was washed with hydrogen peroxide and sorted under a binocular microscope for 
156 all recognizable hard shelled biogenic components. The latter include molluscs, serpulids,

157 echinoids, bryozoans, decapods, ostracods, brachiopods, fishes and whale bone fragments.

158 Molluscs were determined at the species level and used for quantitative comparisons. Both

159 live and dead specimens were counted. The total number of bivalve individuals was counted

160 as the highest number of right or left valves and half of the remaining, the latter roughly

161 corresponding to the number of unmatchable valves (i.e., 50 left and 48 right valves:

$16250+(48 / 2)=74$ individuals $)$. Gastropods were equated to the number of apices. Nomenclature 163 used follows Hansson (1998).

164 Data analyses. The Kosterfjord dataset, including 1575 specimens belonging to 45 mollusc 165 species, formed the basis for the analyses of sample diversity and trophic structure.

166 Rarefaction curves (Hurlbert 1971) were calculated to compare mollusc sample species

167 richness of the whale fall sample (W1) with species richness of the background samples (B1,

168 B2, B3). The height of a rarefaction curve is a function of community species richness, and

169 its curve steepness is a function of species evenness, allowing a comparison of diversity in

170 samples of different sizes (Hayek \& Buzas 1997, Gray 2000). Diversity indices were also

171 calculated for each sample, each influenced to some degree by community structure. The

172 Simpson index is affected by the 2-3 most abundant species and represents the probability

173 that 2 individuals chosen at random from a sample belong to the same species (Hayek \&

174 Buzas 1997). Shannon's index (H) provides a measure of uncertainty in the identity of an

175 individual pulled randomly from a sample (Hayek \& Buzas 1997), with low H indicating a

176 fairly high certainty of outcome (i.e. low diversity). $\mathrm{H}$ is thus insensitive to rare (especially

177 singleton) species. Fisher's $\alpha$ is a number close to that of species expected to be represented

178 by only a single (i.e. rare) individual (Hayek \& Buzas 1997). The four Kosterfjord samples

$179(\mathrm{n}=1575)$ were also used for trophic analysis. Seven trophic categories were distinguished

180 consistently following the Molluscan Life Habits Databases (Todd 2000). Abbreviations

181 appropriate for the present study were used: chemosymbiotic deposit feeders (DC),

182 suspension feeders (SU), subsurface deposit feeders (DU), surface deposit feeder (DS),

183 herbivores, including herbivores on fine-grained substrates, herbivores on rock, rubble or

184 coral substrates and herbivores on plant or algal substrates (HE) and predatory carnivores,

185 including scavengers (CP). Comparisons were expressed through percent of number of

186 specimens (n, abundance) and number of species (S, richness) for each category.

187 The larger dataset, made by merging the Kosterfjord data with literature data (Appendix 1),

188 includes five samples form a North Sea pockmark with active methane seeps and three from 
the surrounding sediments at 150-166 m depth (Dando et al. 1991), three samples collected in the Gullmar Fjord during periods of low oxygen conditions (Josefson 1986, 1987, 1988), and 82 samples from the west coast of Sweden ranging from 26 to $106 \mathrm{~m}$ depth (Agrenius 2001, 2002, 2003, 2005). The latter were collected in the Kattegat and the Skagerrak and are subdivided in samples from fjords (25), coastal areas (35) and open sea settings (22). The samples from the North Sea pockmark were collected with a Smith-McIntyre grab sampling $0.1 \mathrm{~m}^{2}$, a gravity corer or a multiple corer ( $\mathrm{S} 1$ to $\mathrm{S} 6$ ), and with a box corer sampling $0.085 \mathrm{~m}^{2}$ (R1, R5, R8) (Dando et al. 1991) (Appendix 2). The samples from the Gullmar Fjords were taken with a modified Smith-McIntyre grab, covering a bottom area of $0.1 \mathrm{~m}^{2}$ and taking a sediment volume of 15.51 (Appendix 2). Each sample (GF1, GF2, GF3) is the mean of 5 replicate grabs (Josefson 1986, 1987, 1988). Each of the Kattegat and the Skagerrak samples derives from the sum of four replicate sub-samples collected with a $0.1 \mathrm{~m}^{2}$ Smith-McIntyre grab (Agrenius 2001, 2002, 2003, 2005) (Appendix 2). Macrofauna was collected by washing the sediment through a $0.5 \mathrm{~mm}$ mesh sieve for the North Sea pockmark samples, and through a or $1 \mathrm{~mm}$ mesh sieve for all the others. The total dataset is made of 97 samples, for a total of 105 mollusc species (gastropods, bivalves, scaphopods) and 26.298 individuals. None of the previous studies specify if live specimens or both live and dead shells were counted, so that it is assumed that the whole dataset is inclusive of both dead and live specimens. If only live specimens were included, the merging of live and live/dead assemblages in the same dataset (e.g. the Kosterfjord dataset and the data derived from the literature) would not alter significantly the results of our analysis. It is shown by a previous analysis of 85 habitat-level live dead molluscan data sets that a strong correlation exists between live and death assemblages, with species dominant in a single live census also dominating the local death assemblage, and species rare or unsampled alive being also rare dead (Kidwell, 2002). Furthermore death assemblages are known to capture environmental gradients as much as living assemblages (Tomašových \& Kidwell 2009, Albano \& Sabelli 2011, Weber \& Zuschin submitted) and comparisons of evenness based on many collections provide reasonably accurate estimates of differences in average large-scale community structure (Olszewski \& Kidwell 2007), so that a study based on both live and death assemblages is considered as informative as one based solely on live specimens. In addition, variation in life span is known to yield little bias of proportional abundances when passing from the live to the death assemblage (Kidwell \& Rothfus 2010). 
221 After removing species occurring only in one sample (singletons), multivariate analysis was performed on a dataset with 68 species and 26.174 individuals $(99.5 \%$ of the original dataset). To overcome problems connected with comparing samples of different size, abundances were transformed into percentages. Percentages were then square-root transformed to de-emphasize the influence of the most abundant taxa and increase the effect of rare species (Clarke \& Warwick 2001), allowing for a stronger correspondence with

227 known environmental gradients (see Tomašových \& Kidwell 2009). Hierarchical agglomerative cluster analysis was performed using the paired group method and the BrayCurtis algorithm (Q mode cluster). Data were elaborated through detrended correspondence analysis (DCA), a multivariate statistical technique widely used with ecological data to ordinate taxa along underlying ecological gradients (Hill \& Gauch 1980). In a DCA plot, axis 1 reflects the primary source of ecological variation in the composition of fauna and axes 2 the additional sources of variation beyond the principal gradient. A similarity percentage analysis (SIMPER, see Clarke \& Warwick 2001) was performed to determine which species were responsible for similarity within groups of samples. Those species for which the ratio of mean similarity to standard deviation of similarity is $>1$ typify the sample group, and were listed in the comparisons. Diversity indices, cluster analysis and DCA analysis were performed with the software PAST (Hammer et al. 2001). SIMPER analysis was performed with the software PRIMER (Clarke \& Warwick 2001). To avoid ambiguities in the final interpretation, the results of the multivariate analyses were evaluated considering possible effects of sampling methods on one side, and of taphonomic processes on species abundances in time-averaged death assemblages on another (Tomašových \& Kidwell 2011).

\section{RESULTS}

245 Whale fall and background community structure. During sampling at the whale fall site the skull, one mandible and some ribs were still visible on the sea floor. Exposed bones were covered in a mixture of bacterial mats (associated with blackened bone regions, indicative of sulphide release) and muddy sediments. No molluscs were seen lying directly over or around the bones during the survey (nor in more than 20 bones brought to the laboratory and analysed over the years). Algal debris was trapped within the bones (e.g. Fucus serratus) and the decapod Hyas araneus was frequently observed close to the skeleton (Figure 2). Bones 
were highly bioeroded and specimens of the bone eating worm Osedax mucofloris were recorded living on collected bone samples, five years after carcass deployment.

254 The sieving residue included molluses, regular and irregular echinoids (Brissopsis lyrifera

255

256

257

258

259

260

261

262

263

264

265

266

267

268

269

270

271

272

273

274

275

276

277

278

279

280

281

282

283 and Spatangus purpureus), brachiopods (Crania sp. and terebratulids), benthic foraminifers, ostracods, serpulids, bryozoans, decapods, fish fragments and teeth and myxinid dental plates. Sample W1 was dominated by the bivalve Thyasira sarsi (51\% of the total), followed by Abra nitida (16.2\%), Tellimya ferruginosa (8\%), Mytilus edulis (4.9\%) and the nuculanid Ennucula tenuis (4.7\%) (Figure 3). Among the gastropods the most abundant were Pusillina sarsii (3.7\%), Cylichna cylindracea (2.5\%) and Alvania punctura (2\%). Specimens of Thyasira sarsi (Figure 4A) and Abra nitida (Figure 4B) were observed alive during sieving operations. Thyasira equalis was the most abundant species in B1, B2 and B3 samples, accounting respectively for the $43.1 \%, 22.9 \%$ and $27.8 \%$ of the total. Besides $T$. equalis, the background samples contained many protobranchiate bivalves, such as Ennucula tenuis, Yoldiella philippiana, Nucula sulcata, Nuculana minuta and N. pernula (Figure 3). Also the semelid Abra nitida and the cardiid Parvicardium minimum were represented in significant quantities in the background sediments.

The background samples B2 and B3 exhibit higher species richness and a more even distribution than W1, that is, W1 is dominated by fewer species (Figure 5). Although W1 derives from a smaller volume of sediments compared with the background samples (see Table 1), it contains a larger number of individuals, and its rarefaction curve reaches an asymptotic shape. This indicates that if a larger volume of similar sediments had been collected from the whale fall, no further taxa would have been added. The diversity indices help to interpret results from rarefaction curves (Table 2). W1 has the highest value of D, the Simpson index of Dominance, being dominated by a few species, and the lowest value of $\mathrm{H}$, the Shannon's index. The Shannon's index is more affected by species in the middle of the species rank sequence which are rare at the whale fall but are abundant in the background samples. The background sediments are in fact characterized by a higher number of rare species than W1, as also highlighted by their high values of the Fisher's $\alpha$ index. B1, the sample with the lower number of individuals, has intermediate values.

Trophism. The two predominant thyasirids, Thyasira sarsi (dominant at W1) and Thyasira equalis (dominant at B1, B2, and B3), are infaunal chemosymbiotic deposit feeders containing symbiotic sulphur-oxidizing bacteria in their gill tissue (Southward 1986). Both of 
them are mixotrophic and can derive part of their nutrition heterotrophically by particulate feeding (Dufour \& Feldbeck 2006). In particular, studies on the nutritional dependence of the two bivalves on chemoautotrophic symbiotic bacteria show that T. equalis has fewer symbiotic bacteria in its gills compared to $T$. sarsi, indicating that the nutritional importance of carbon fixed by the bacteria is less in T. equalis (Dando \& Spiro 1993, Dufour 2005). T. sarsi instead derives 50-100 \% of its tissue carbon from carbon fixed by bacteria (Spiro et al. 1986, Schmaljohann et al. 1990). The chemosymbiotic trophic group has the highest abundance in all the four samples, but the lowest species richness (Figure 6). Like chemosymbiotic deposit feeders, surface deposit feeders have a high overall abundance but low species richness, being represented only by the semelid Abra nitida, more abundant in W1 than in the background community. Subsurface deposit feeders (nuculids, nuculanids, yoldiids and dentaliids) have both high abundance and high diversity in B1, B2 and B3 (38\%, $46 \%$ and $47.9 \%$ respectively). The same subsurface deposit feeders are present in all samples but their abundance in $\mathrm{W} 1$ is the lowest (8.4\%). Suspension feeders have a high species richness, both in whale fall and background fauna. The mytilids Mytilus edulis and Musculus discors and the montacutid Tellymia ferugginosa characterise sample W1, whereas pectinids, anomiids and cardiids are typical of B1, B2 and B3. Herbivores are diverse but rare in all samples. Those associated with the whale fall, such as the rissoids Rissoa lilacina and Pusillina sarsi, are typical of shallower settings where they are associated to algae (Laminaria spp.) or seagrass (Zostera marina) (Warén 1996). The rissoid species Onoba cf. tumidula was recently found also at relatively shallow water vents $(557-713 \mathrm{~m})$ in the North Atlantic (Schander et al. 2010), suggesting a rather wide environmental range for the whole family. Carnivores are the least represented among the trophic categories, only the burrowing Cylichna cylindracea was present in the whale fall sample.

Extreme vs normal benthic environments. The samples collected at the Kosterfjord whale fall and in the surrounding sediments were compared with samples from a shallow water North Sea methane seep area, from soft sediment samples collected in the Gullmar Fjord at $115 \mathrm{~m}$ depth at times of hypoxic bottom water conditions and with samples collected in normal marine bottoms along the Swedish west coast. The cluster agglomerative diagram shows that samples form four main clusters at rather high value of similarity (around 0.4: Figure 7). Cluster 1 groups samples from "organic-rich sediments", i.e., the whale fall sample (W1) and the three samples from the Gullmar Fjord (GLF1, 2, 3). Cluster 2 groups samples from the methane seep area and comprises all samples related to the North Sea pockmark 
with active methane seepage, whether they were collected from the side of the pockmark (R5, $\mathrm{R} 8, \mathrm{~S} 1, \mathrm{R} 1, \mathrm{~S} 2)$ or from the surrounding bottom sediments not directly related to methane seepage (S4, S5, S6). Cluster 3 contains samples from the Swedish west coast with average depth $<50 \mathrm{~m}$, comprising those from fjords and those from onshore settings. Cluster 4 groups all offshore soft bottom samples, i.e., with an average depth $>50 \mathrm{~m}$. The Kosterfjord background samples (B1, B2, B3) became included in the latter group, in particular with samples collected in the same area at 91-102 m depth (SK13 and SK14: Figure 7, Appendix 2). This result confirms that the distribution of species abundances in samples is relatively unaffected by sampling and processing methods. Consistently with the cluster analysis, in the DCA diagram the four main sample clusters show practically no overlap (Figure 8). The first two axes of the ordination, DC1 and DC2, are representative of the full distribution of data, explaining $90.7 \%$ of the variance $(\mathrm{DC} 1=65.7 \%, \mathrm{DC} 2=25 \%)$. A small overlap occurs between onshore and offshore samples, consistently with a gradual depth-related transition between samples. If in the dendrogram fjords and onshore samples were grouped together, in the DCA they are well separated, forming two distinct sub-clusters, fjord samples at low DC2 values and onshore samples at high DC2 values. The ordination of samples along DC1 follows a depth gradient (see Appendix 3). Onshore and fjord samples score the lowest DC1, onshore samples ranging 28-59 m depth, fjord samples 21-47 m. Offshore samples have intermediate DC1 values, their depth gradually shifting from 50 to $125 \mathrm{~m}$ with increasing DC1 scores. Consistently, W1 and samples from the Gullmar Fjord, collected at a depth of $115 \mathrm{~m}$, have intermediate DC1 values. Samples from the methane seep area, collected between 150 and $-166 \mathrm{~m}$, rest on the right part of the diagram. Samples are also widely scattered along DC2. Gullmar Fjord samples have the lowest DC2 values, followed by W1,

340 fjord samples and some of the samples from the methane seep area, merging with onshore and offshore samples at high DC2 scores. Concerning the possible occurrence of both dead and live assemblages in our dataset, when samples are pooled, we can expect that variation in

343 species composition among samples will be higher when living or death assemblages are 344 ordinated separately. The centroid of such pooled assemblages should be located between the centroids of living and death assemblages (Tomašových \& Kidwell 2011). Given the distribution of environmentally separable groups of sample in the multidimensional space, at clearly separable DC2 values (Figure 8), an eventual separation of live and dead assemblages within each cluster would not alter the significance of the difference between clusters. 
SIMPER analysis allowed us to highlight which taxa are responsible for the similarity within samples forming the five main groups (Table 3). The whale fall and the Gullmar Fjord samples have the highest similarity among the five groups. In particular, their similarity is given by the occurrence in all of them of the bivalves $T$. sarsi and A. nitida, with a cumulative contribution of the $76.7 \%$. Even if T. sarsi occurs in two of the samples collected inside of the North Sea pockmark (R8 and S1), the largest contribution to the similarity between samples from the methane seep area is given by the thyasirids $T$. equalis and $T$. obsoleta. Onshore, offshore and fjord samples are dominated by the bivalves Kurtiella bidentata, Abra nitida, nuculanids like Ennucula tenuis and Nucula nitidosa and the gastropods Hyla vitrea, which contribute with different percentage within each group.

\section{DISCUSSION}

The Kosterfjord whale fall. The quantitative analysis of the Kosterfjord samples shows that the presence of a minke whale carcass on the sea floor at shelf depths still influences the composition and structure of the benthic community five years after its implantation. Although some species are shared between the whale fall and the background community, the whale-fall community clearly shows a lower diversity in its species composition, a different ranking of species, and dominance of the chemosymbiotic bivalve Thyasira sarsi. The Kosterfjord whale fall is similar to sites with high organic input in shallow water environments (see Pearson \& Rosenberg 1978). Rarefaction curves and diversity indices show a markedly lower diversity in the area close to the source of organic matter with respect to the background sediments. The high abundance of $T$. sarsi in the sediments closely associated with the skeleton suggests that the decay of the whale organic matter created an ephemeral habitat with high sulphate reduction rates, i.e. a certain degree of reliance on chemosynthesis. The density of $T$. sarsi is in fact dependent upon the sulphate reduction rate in the sediment (Dando et al. 2004). Sulphide conditions could have been further favored by the presence of macroalgae trapped within the bones, which can alone introduce reduced compounds in the sediments (Dando et al. 1993). The species T. sarsi is widely distributed in the NE Atlantic and is generally found in association with organic-rich sediments with high total sulphide concentrations (Dando \& Southward 1986). In the North Sea and in the Skagerrak T. sarsi is associated with sewage-polluted fjords, anoxic fjords, fish farms and active methane seeps (Dando et al. 1991, Dando \& Spiro 1993, Dando et. al. 1994, Rosenberg et al. 2002, Kutti et al. 2007), with a depth range of 50-340 m (Dufour 2005). 
collection, T. equalis, is the most common thyasirid on the North European continental shelf, preferring sediments with less-organics with respect to $T$. sarsi, possibly avoiding hydrogen sulphide rich sediments (Dando \& Southward 1986).

385

386

387

388

389

390

391

392

393

394

395

396

397

398

399

400

401

402

403

404

405

406

407

408

409

410

411

412

413

The opportunist species Abra nitida, common along the northern part of the Swedish west coast, is a density-dependent species unaffected by turbid conditions (Josefson 1982). Its high abundance at the whale-fall site could be linked to the presence of high organic content, as observed in fish farm areas with increased food supply (Kutti et al. 2007). The abundance of Tellymia ferugginosa in the whale-fall sample, a small bivalve living symbiotically in the burrow of the echinoid Echinocardium cordatum (Gillan \& De Ridder 1997), is indicative of the occurrence of the echinoid itself. Echinocardium cordatum, a deep burrower, may not have been directly collected due to the shallow depth of our sampling. The species hosts ectosymbiotic sulphide-oxidizing bacteria, Thyothrix like, in its intestinal caecum and is known to burrow below or at the level of the oxidized-reduced interface, ingesting both surface and deep reduced sediments. This symbiosis opens an access for E. cordatum to sulphide-rich habitats (Temara et al. 1993, Brigmon \& De Ridder 1998) and adds further evidence for the presence of a chemosynthetic ecological niche at this shallow-water whale fall site (Bromely et al. 1995). As with E. cordatum, the presence of other deeper burrowers may have been overlooked because of the shallow sampling depth within the sediment. Among these missing taxa may be the lucinid bivalves, chemosymbiotically hosting sulphuroxidizing bacteria in their gill tissue and living in burrows of up to $20 \mathrm{~cm}$ depth (Dando et al. 1986).

Both the whale fall and the surrounding sediment communities record the presence of coastal species, such as the mytilids Mytilus edulis and Musculus cf. discors and littorinid gastropods, which were probably transported down-slope by bottom currents. Most of the gastropods found at the whale fall site, including the rissoids, are known to dwell on sea weeds, and were possibly transported by drifting algae, as shown by algal debris around whale bones (Figure 2). Because alive and dead specimens were not distinguished during our sampling procedures, it is not possible here to support the hypothesis that some rissoid species could be adapted to live also in reducing environments, as recently found in some North Atlantic vents (Schander et al. 2010).

Environmental gradients on the Swedish shelf. The species level, multivariate comparison of the Kosterfjord samples with samples collected from soft-bottom sediments across the 
west Swedish coast allowed a better interpretation of environmental parameters controlling the faunal composition at the Kosterfjord whale fall. In this study, the ordination of samples along the principal axis of the DCA is controlled by water depth. The faunal composition

417 changes continuously along a depth gradient, with shallower samples on the left side of the

418 diagram and deeper on the right side. This result is in accordance with the interpretation that 419 in marine environments water depth is the single most important factor controlling the 420 distribution of benthic organisms (see Gauch 1982), and as amply proven in other case studies (Scarponi \& Kowaleski 2004, Dominici et al. 2008, Danise 2010).

422 The significance of the DC2 ordination is generally more difficult to interpret, because 423 variations in water depth sum up continuously changing values of other parameters that 424 directly affect the distribution of benthic species, such as food availability, water energy, 425 substrate texture, seasonality, oxygen content and salinity. Samples from reducing soft bottoms are mainly distributed at low DC2 scores, particularly those from the Gullmar Fjord, where bottom waters are periodically affected by low oxygen conditions (Josefson 1987, Josefson \& Wibdon 1988, Dando \& Spiro 1993). The three samples included in this study were collected between 1985 and 1987, at a time of re-colonization of the sediments by $T$. sarsi after a period of oxygen depletion resulting in the death of the bottom fauna. Dando \& Spiro (1993) report high concentrations of total reduced sulphur in the Gullmar Fjord sediments in 1986, together with negative $\delta^{13} \mathrm{C}$ values in the gills of collected specimens of $T$. sarsi, indicating a significant carbon input from autotrophic endosymbiotic bacteria. In addition, samples from the large North Sea pockmark are characterized by the presence of high total sulphide concentrations in the surface layers, as compared to surrounding areas

436 (Dando et al. 1991). In particular, both samples R8 and S1 which have low DC2 values, host 437 the bivalve T. sarsi with negative $\delta^{13} \mathrm{C}$ values (Dando et al. 1991). Since macrobenthic communities associated with fjords, organic enriched sediments and high sulphide methane seeps all occur in the lower part of the diagram and communities from open marine, oxygenated, environments in the upper part, the DC2 score may be a direct measure of the degree of sulphide concentration and an indirect measure of oxygen level of soft bottom sediments.

443 The general picture that can be drawn from our study of north European shelf molluscs shows 444 that the benthic community structure at the Kosterfjord whale fall is similar to that of communities developed in other organic-rich, sulphide environments. In particular, among

446 the secondary colonisers of the enriched sediments at the whale fall are the symbiont- 
447 containing thyasirids, suggesting an ecological succession similar to that of other organic 448 rich-sediments (Pearson \& Rosenberg 1978, Dando et al. 2004). A global comparison of 449 whale-fall communities is hampered by the lack of relevant studies at comparable 450 environmental conditions. In comparison with 219-254 $\mathrm{m}$ whale-fall communities in the 451 northwest Pacific (Fujiwara et al. 2007), the Kosterfjord whale fall lacks molluscs typical of

452 deep water, such as the mytilid mussels (Adipicola pacifica) and the cocculinid limpets.

453 Among the bathymodiolin mussels, Idas simpsoni has been described from trawled bones on 454 the North Sea shelf (Marshall 1900, Warén 1991, Tebble 1996) and in oil-polluted areas 455 (Hartley \& Watson 1993, Southward 2008), but was not found at the Kosterfjord whale fall 456 during the ROV survey, careful examination of multiple recovered bones or in sediment 457 samples. In a time-series study of oil-polluted sediments around North Sea wells and 458 platforms, the benthic community responded to high levels of oil contamination with the 459 appearance of the bathymodiolin I. simpsoni, followed by T. sarsi when oil concentrations 460 gradually lowered (Hartley \& Watson 1993).

\section{Conclusion}

462 Our evidence suggests that the Kosterfjord whale-fall mollusc community is structured 463 around species that exploit a variety of food sources on the continental shelf, including heterotrophs and chemoautotrophs. This result is similar to that recorded from a fossil analog 465 from the Pliocene of Italy (Dominici et al. 2009, Danise et al. 2010). However, it is in contrast with the data on the polychaete fauna. To date a total of 7 new species of polychaete have been recorded from the Kosterfjord whale fall, of which just 3 are present at other organic-rich settings such as fish-farms (Glover et al. 2005, Wiklund et al. 2009a, 2009b, Wiklund pers. comm.). This may well be partly because the polychaete fauna of organic-rich

470 habitats is less well studied than the mollusc fauna, but the presence of specialists such as

471 Osedax mucofloris at Kosterfjord is in contrast with the pattern for Mollusca. From an 472 ecological perspective, our data suggest that shelf-depth whale-falls are a natural analog to 473 areas of organic pollution, such as oil spillages and fish farms, and as such may well offer 474 interesting insights into natural bioremediation at these habitats. From an evolutionary 475 perspective, small carcasses at shelf-depths may provide an avenue for speciation in 476 polychaetes, but not necessarily in molluscs.

\section{ACKNOWLEDGEMENTS}


478 The authors thank Tomas Lundälv at RV Lophelia for assistance with ROV operations and 479 video documentation; Ingemar Adolfsson, Anders Billing at RV Nereus for assistance with 480 sampling, and Helena Wiklund for help with sample processing. A special thanks to Alf 481 Josefson for providing copy of the Gullmar Fjord reports. Adam Tomašových and Martin 482 Zuschin are thanked for assistance in interpreting the possible influence of taphonomic 483 effects on the interpretation of results. The manuscript was improved by helpful comments 484 from Paul Dando and three other anonymous reviewers. We dedicate this manuscript to the 485 late Hans G. Hansson for inspiring discussions and the early suggestion to sink a whale in the 486 Koster area. Funding was provided to TGD from the Swedish Research Council. 


\section{REFERENCES}

491 Agrenius S (2001) Övervakning av mjukbottenfaunan längs Sveriges västkust. Rapport från 492 verksamheten år 2001. Avtal nr 2120103

493 Agrenius S (2002) Övervakning av mjukbottenfaunan längs Sveriges västkust. Rapport från 494 verksamheten år 2002. Avtal nr 2120203

495 Agrenius S (2003) Övervakning av mjukbottenfaunan längs Sveriges västkust. Rapport från 496 verksamheten år 2003. Avtal nr 2120303

497 Agrenius S (2005) Övervakning av mjukbottenfaunan längs Sveriges västkust. Rapport från 498 verksamheten år 2003. Avtal nr 2120503

499 Albano PG, Sabelli B (2011) Comparison between death and living molluscs assemblages in 500 a Mediterranean infralittoral off-shore reef. Palaeogeogr Palaeoclimatol Palaeoecol 310:206501215

502 Braby CE, Rouse GW, Johnson SB, Jones WJ, Vrijenhoek RC (2007) Bathymetric and 503 temporal variation among Osedax boneworms and associated megafauna on whale-falls in 504 Monterey Bay, California. Deep-Sea Res I 54:1773-1791

505 Brigmon RL, De Ridder C (1998) Symbiotic relationship of Thiothrix spp. with an 506 echinoderm. Appl Environ Microbiol 64:3491-3495

507 Bromley RG, Jensen M, Asgaard U (1995) Spatangoid echinoids: deep-tier trace fossils and 508 chemosymbiosis. N Jb Geol Palaont Abh 195:25-35

509 Clarke KR, Warwick RM (2001) Changes in marine communities: an approach to statistical 510 analysis and interpretation, $2^{\text {nd }}$ edition. PRIMER-E: Plymouth, UK

511 Dahlgren TG, Glover AG, Baco A, Smith CR. (2004) Fauna of whale falls: systematics and 512 ecology of a new polychaetes (Annelida : Chrysopetalidae) from the deep Pacific Ocean.

513 Deep-Sea Res Pt I 51:1873-1887

514 Dahlgren TG, Wiklund H, Källström B, Lundälv T, Smith CR, Glover A (2006) A shallow515 water whale-fall experiment in the North Atlantic. Cah Biol Mar 47:385-389 
516 Dando PR 2010. Biological communities at marine shallow-water vent and seep sites. In:

517 Kiel S (ed) The Vent and Seep Biota. Springer

518 Dando PR, Southward AJ (1986) Chemoautotrophy in bivalve molluses of the genus

519 Thyasira. J Mar Biol Ass UK 66:915-929

520 Dando PR, Spiro B (1993) Varying nutritional dependence of the thyasirid bivalves Thyasira

521 sarsi and T. equalys on chemoautotrophic symbiotic bacteria, demonstrated by isotope ratios

522 of tissue carbon and shell carbonate. Mar Ecol Prog Ser 92:151-158

523 Dando PR, Southward AJ, Southward EC (1986) Chemoautotrophic symbionts in the gills of

524 the bivalve mollusc Lucinoma borealis and the sediment chemistry of its habitat. P Roy Soc

525 B-Biol Sci 227:227-247

526 Dando PR, Austen MC, Burke RJ, Kendall MA, Kennicutt MC, Judd AG, Moore DC,

527 Schmaljohann R, Southward AJ (1991) Ecology of a North Sea pockmark with an active

528 methane seep. Mar Ecol Prog Ser 70:49-63

529 Dando PR, Fenchel T, Jensen P, O'Hara SCM, Niven SJ., Schuster U (1993) The ecology of

530 gassy, organic rich sediment in a shallow subtidal area on the Kattegat coast of Denmark.

531 Mar Ecol Prog Ser 100:265-271

532 Dando PR, Bussmann I, Niven SJ, O’Hara SCM, Schmaljohann R, Taylor LJ (1994) A

533 methane seep area in the Skagerrak, the habitat of the pogonophore Siboglinum poseidoni and

534 the bivalve mollusc Thyasira sarsi. Mar Ecol Prog Ser 107:157-167

535 Dando PR, Southward AJ, Southward EC (2004) Rates of sediment sulphide oxidation by the 536 bivalve mollusc Thyasira sarsi. Mar Ecol Prog Ser 280:181-187

537 Danise S (2010) Shallow-water whale-fall communities. PhD thesis, Universtà degli Studi di 538 Firenze, Italy

539 Danise S, Dominici S, Betocchi U (2010) Mollusk species at a Pliocene shelf whale fall

540 (Orciano Pisano, Tuscany). Palaios 25:449-556

541 Distel DL, Baco AR, Chuang E, Morrill W, Cavanough C, Smith CR (2000) Do mussels take 542 wooden steps to deep-sea vents? Nature 403:725-726 
543 Dominici S, Conti C, Benvenuti M (2009) Foraminifer communities and environmental

544 change in marginal marine sequences (Pliocene, Tuscany, Italy). Lethaia 41:447-460

545 Dominici S, Cioppi E, Danise S, Betocchi U, Gallai G, Tangocci F, Valleri G, Monechi S

546 (2009) Mediterranean fossil whale falls and the adaptation of mollusks to extreme habitats.

547 Geology 37:815-818

548 Dubilier N, Bergin C, Lott C (2008) Symbiotic diversity in marine animals: The art of

549 harnessing chemosynthesis. Nature Review 6:725-740

550 Dufour SC (2005) Gill snatomy and the evolution of symbiosis in the bivalve family

551 Thyasiridae. Biol Bull 208:200-212

552 Dufour SC, Felbeck H (2006) Symbiont abundance in thyasirids (Bivalvia) is related to

553 particulate food and sulphide availability. Mar Ecol Prog Ser 320:185-194

554 Duperon S (2010) The diversity of deep-sea mussels and their bacterial symbioses, in: Kiel S 555 (ed) The Vent and Seep Biota. Springer

556 Fujiwara Y, Kawato M, Yamamoto T, Yamanaka T, Sato-Okoshi W, Noda C, Tsuchida S,

557 Komai T, Cubelio SS, Sasaki T, Jacobsen K, Kubokawa K, Fujikura K, Maruyama T,

558 Furushima Y, Okoshi K, Miyake H, Miyazaki M, Nogi Y, Yatabe A, Okutani T (2007)

559 Three-year investigations into sperm whale-fall ecosystems in Japan. Mar Ecol 28:219-232

560 Gauch HG (1982) Multivariate analysis in community ecology. Cambridge University Press,

561 Cambridge, UK

562 Gillan C, De Ridder C (1997) Morphology of a ferric iron-encrusted biofilm forming on the 563 shell of a burrowing bivalve (Mollusca). Aquat Microb Ecol 12:1-10

564 Glover AG, Kallstrom B, Smith CR, Dahlgren TG (2005) World-wide whale worms? A new 565 species of Osedax from the shallow North Atlantic. Proceed Royal Soc London, Ser B-Biol 566 Scie 272:2587-2592

567 Glover AG, Higgs ND, Bagley PM, Carlsson R, Davies AG, Kemp KM, Last KS, Norling K, 568 Rosenberg R, Wallin K, Källström B, Dahlgren TG (2010) A live video observatory reveals 569 temporal processes at a shelf-depth whale-fall. Cah Biol Mar 51:375-381 
570 Gray JS (2000) The measurement of marine species diversity, with an application to the

571 benthic fauna of the Norwegian continental shelf. J Exp Mar Biol Ecol 250:23-49

572 Hammer Ø, Harper DAT, Ryan PD (2001) PAST: Paleontological statistics software package

573 for education and data analysis: Palaeontologia Electronica 4: 1-9. https://palaeo-

574 electronica.org/2001_1/past/issue1_01.htm

575 Hansson HG (1998) NEAT (North East Atlantic Taxa): Scandinavian marine Mollusca

576 Check-List. Internet Ed., Aug. 1998. http://www.tmbl.gu.se

577 Hartley JP, Watson TN (1993) Investigation of a North Sea oil platform drill cuttings pile.

578 Proceedings of 25th Annual Offshore Technology Conference, Houston, Texas, p. 749-756

579 Hayek LA, Buzas MA (1997) Surveying natural populations. Columbia University Press,

580 New York

581 Hill MO, HG Gauch Jr (1980) Detrended correspondence analysis: an improved ordination

582 technique. Vegetatio 42:47-58

583 Hurlbert SH (1971) The non-concept of species diversity: a critique and alternative

584 parameters. Ecol 52:577-586

585 Josefson AB (1982) Regulation of population size, growth, and production of a deposit-

586 feeding bivalve: a long-term field study of three deep-water populations off the Swedish west

587 coast. J Exp Mar Biol Ecol 59:125-150

588 Josefson AB (1985) Distribution of diversity and functional groups of marine benthic infauna

589 in the Skagerrak (eastern North Sea) - Can larval availability affect diversity? Sarsia 70:229-

$590 \quad 249$

591 Josefson AB (1986). Övervakning av mjukbottenfauna längs Sveriges västkust. Rapport från 592 verksamheten 1985. Naturvärdsverket Rapp. 3247

593 Josefson AB (1987). Övervakning av mjukbottenfauna längs Sveriges västkust. Rapport från

594 verksamheten 1985. Naturvärdsverket Rapp. 3335

595 Josefson AB (1988). Övervakning av mjukbottenfauna längs Sveriges västkust. Rapport från 596 verksamheten 1985. Naturvärdsverket Rapp. 3504 
597 Josefson AB, Widbom B (1988) Differential response of benthic macrofauna and meiofauna 598 to hypoxia in the Gullmar Fjord basin. Mar Biol 100:31-40

599 Jones WJ, Won YJ, Maas PAY, Smith PJ, Lutz RA, Vrijenhoek RC (2006) Evolution of 600 habitat use by deep-sea mussels. Mar Biol 148:841-851

601 Kidwell SM (2002) Time-averaged molluscan death assemblages: Palimpsests of richness, 602 snapshots of abundance, Geology 30: 803-806

603 Kidwell SM, Rothfus TA (2010) The living, the dead, and the expected dead: variation in life 604 span yields little bias of proportional abundances in bivalve death assemblages. Paleobiology $60536: 615-640$.

606 Kutti T, Ervik A, Høisæter T (2007) Effects of organic effluents from a salmon farm on a 607 fjord system. III. Linking deposition rates of organic matter and benthic productivity. 608 Aquaculture 282:47-53

609 Marshall JT (1900) On a British Species of Myrina, with a note on the genus Idas. J Malacol $610 \quad 7: 167-170$

611 Olszewski TD, Kidwell SM (2007) The preservational fidelity of evenness in molluscan 612 death assemblages. Paleobiology 33:1-23.

613 Palm A, Cousins I, Gustafsson O, Axelman J, Grunder K, Broman D, Brorström-Lunden E 614 (2004) Evaluation of sequentially-coupled POP fluxes estimated from simultaneous 615 measurements in multiple compartments of an air-water-sediment system. Environ Pollut $616 \quad 128: 85-97$

617 Pavlyuk ON, Trebukhova YA, Tarasov VG (2009) The impact of implanted whale carcass on 618 nematode communities in shallow water area of Peter the Great Bay (East Sea). Ocean Sci J $619 \quad 44: 181-188$

620 Pearson TH, Rosenberg R (1978) Macrobenthic succession in relation to organic enrichment 621 and pollution of the marine environment. Oceanogr Mar Biol A Rev 16:229-311

622 Rosenberg R, Agrenius S, Hellman B, Nilsson HC, Norling K (2002) Recovery of marine 623 benthic habitats and fauna in a Swedish fjord following improved oxygen conditions. Mar 624 Ecol Prog Ser 234:43-53 
625 Rouse GW, Goffredi SK, Vrijenhoek RC (2004) Osedax: Bone-eating marine worms with 626 dwarf males. Science 305:668-671

627 Rouse GW, Goffredi SK, Johnson SB, Vrijenhoek RC (2011) Not whale-fall specialists, 628 Osedax worms also consume fishbones. Biol Lett 7:736-739

629 Scarponi D, Kowalewski M (2004) Stratigraphic paleoecology: bathymetric signatures and 630 sequence overprint of mollusk associations from upper Quaternary sequences of the Po Plain, 631 Italy. Geology 32:989-992

632 Schander C, Rapp HT, Kongsrud JA, Bakken T, Berge J, Cochrane S, Oug E, Byrkjedal I, 633 Todt C, Cedhagen T, Fosshagen A, Gebruk A, Larsen K, Levin L, Obst M, Pleijel F, Stöhr S, 634 Warén A, Mikkelsen NT, Hadler-Jacobsen S, Keuning R, Heggøy Petersen K, Thorseth IH, 635 Pedersen RB (2010) The fauna of hydrothermal vents on the Mohn Ridge (North Atlantic). 636 Mar Biol Res 6:155-171

637 Schmaljohann R, Faber E, Whiticar MJ, Dando PR (1990) Co-existence of methane- and 638 sulphur-based endosymbiosis between bacteria and invertebrates at a site in the Skagerrak. 639 Mar Ecol Prog Ser 61:119-124

640 Smith CR (2006) Bigger is better: The role of whales as detritus in marine ecosystems. In:

641 Estes J (ed) Whales, Whaling and Ocean Ecosystems: Berkeley, University of California 642 Press, p 284-299

643 Smith CR, Kukert H, Wheatcroft RA, Jumars PA, Deming JW (1989) Vent fauna on whale 644 remains. Nature 341:27-28

645 Smith CR, Baco AR (2003) Ecology of whale falls at the deep-sea floor. Oceanogr Mar Biol 646 Annual Review 41:311-354

647 Southward EC (1986) Gill symbionts in thyasirids and other bivalve molluscs. J mar biol Ass 648 UK 66:889-914

649 Southward EC (2008) The morphology of bacterial symbiosis in the gills of mussels of the 650 geners Adipicola and Idas (Bivalvia: Mytilidae). J Shellfish Res 27:139-146

651 Spiro B, Greenwood PB, Southward AJ, Dando PR (1986) ${ }^{13} \mathrm{C} /{ }^{12} \mathrm{C}$ ratios in marine 652 invertebrates from reducing sediments: confirmation of nutritional importance of 653 chemoautotrophic endosymbiotic bacteria. Mar Ecol Prog Ser 28:233-240 
654 Tebble N (1966) British bivalve seashells: a handbook for identification. The British Museum 655 (Natural History), London

656 Temara A, De Ridder C, Kuenen JC, Robertson LA (1993). Sulfide oxidizing bacteria in the 657 burrowing echinoid, Echinocardium cordatum (Echinodermata). Mar Biol 115:179-185

658 Todd JA (2000) Introduction to molluscan life habits databases, updated March 27, 2001. 659 http://eusmilia.geology.uiowa.edu/database/mollusc/mollusclifestyles.htm

660 Tomašových A, Kidwell SM (2009) Preservation of spatial and environmental gradients by 661 death assemblages. Paleobiology 35:122-148.

662 Tomašových A, Kidwell SM (2011) Accounting for the effects of biological variability and 663 temporal autocorrelation in assessing the preservation of species abundance. Paleobiology $664 \quad 37: 332-354$.

665 Van Weering TCE, Berger GV, Kalf J (1987) Recent sediment accumulation in the 666 Skagerrak, northeastern North Sea. Neth J Sea Res 21:177-189

667 Warén A (1991) New and little known Mollusca from Iceland and Scandinavia. Sarsia: 76, $668 \quad 53-124$

669 Warén A (1996) Ecology and systematics of the northern European species of Rissoa and 670 Pusillina (Prosobranchia: Rissoidae). J Mar Biol Ass UK 76:1013-1059

671 Weber K, Zuschin M (submitted) Delta-associated molluscan life and death assemblages in 672 the northern Adriatic Sea: Implications for palaeoecology, regional diversity and 673 conservation. Palaeogeogr Palaeoclimatol Palaeoecol

674 Wiklund H, Glover AG, Johannessen P, Dahlgren TG (2009a) Cryptic speciation at organic675 rich marine habitats: a new bacteriovore annelid from whale-fall and fish farms in the North 676 East Atlantic. Zool J Linn Soc 155: 774-785

677 Wiklund H, Glover AG, Dahlgren TG (2009b) Three new species of Ophryotrocha 678 (Annelida: Dorvilleidae) from a whale-fall in the North-East Atlantic. Zootaxa 2228: 43-56

679 Wisshak M, Gettidis M, Freiwald A, Lundalv T. (2005) Bioerosion along a bathymetric 680 gradient in a cold temperate setting (Kosterfjord, SW Sweden): an experimental study. Facies $681 \quad 51: 93-117$ 


\section{FIGURE CAPTIONS}

686 Figure 1. Map showing the North Sea, the Skagerrak and Kattegat basins. The location of the 687 methane seep area studied by Dando et al. (1991) and the experimental whale-fall site, next to 688 the Sven Lovén Centre for Marine Sciences, Tjärnö, are highlighted. Modified from Palm et 689 al 2004.

690 Figure 2. Remotely operated vehicle video stills showing the minke whale skeleton 5 years 691 after implantation. A. Minke whale skull covered by muddy sediment and sulphides. B.

692 Minke whale ribs partially covered by sediments and sulphides, showing intense bioerosion.

693 The decapod Hyas araneus in the upper part of the figure, algal debris (Fucus serratus on the 694 right) trapped within whale bones.

695 Figure 3. Percentage abundance of the quantitatively important species $(>2 \%)$ for each of the 696 four Kosterfjord samples.

697 Figure 4. Live bivalves collected at the Kosterfjord whale fall. A. Specimen of Thyasira 698 sarsi collected from the sediments besides whale bones. B. Specimen of Abra nitida.

699 Figure 5. Rarefaction curves with 95\% confidence intervals (vertical bars) or the whale fall 700 (W1) and the background samples (B1, B2, B3).

701 Figure 6. Trophic analysis expressed through percent of number of individuals (abundance) 702 and number of species (richness). Trophic categories: chemosymbiotic deposit feeders (DC), 703 suspension feeders (SU), subsurface deposit feeders (DU), surface deposit feeder (DS),

704 herbivores (HE) and predatory carnivores, including scavengers (CP).

705 Figure 7. Hierarchical agglomerative cluster (paired group method) based on the Bray-Curtis 706 algorithm. For similarity values of 0.3-0.4 samples group in four main clusters.

707 Figure 8. DCA q-mode diagram. Each point in the diagram correspond to one sample of the 708 dataset $(n=97)$. Samples are grouped according to the clusters recognized after the 709 hierarchical agglomerative cluster analysis. Onshore and fjord samples can be grouped in two 710 distinct sub-clusters. 


\section{TABLE CAPTIONS}

715 Table 1. Site and sampling information.

716 Table 2. Species abundance, number of individuals and diversity indices of the studied 717 samples.

718 Table 3. Characteristic species of each group of samples calculated for standardized data set 719 and square-root transformed abundances using similarity percentage analysis (SIMPER, 720 Clarke \& Warwick 2001). 
724 FIGURES
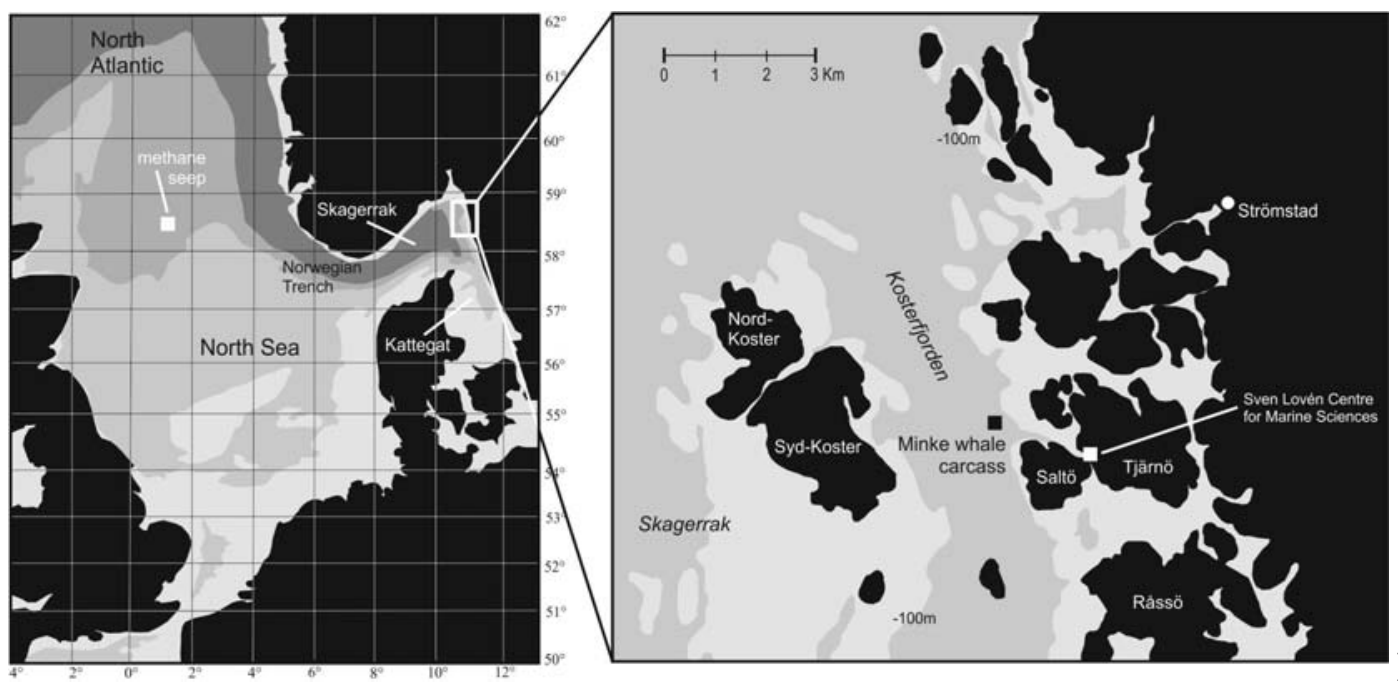

Figure 1
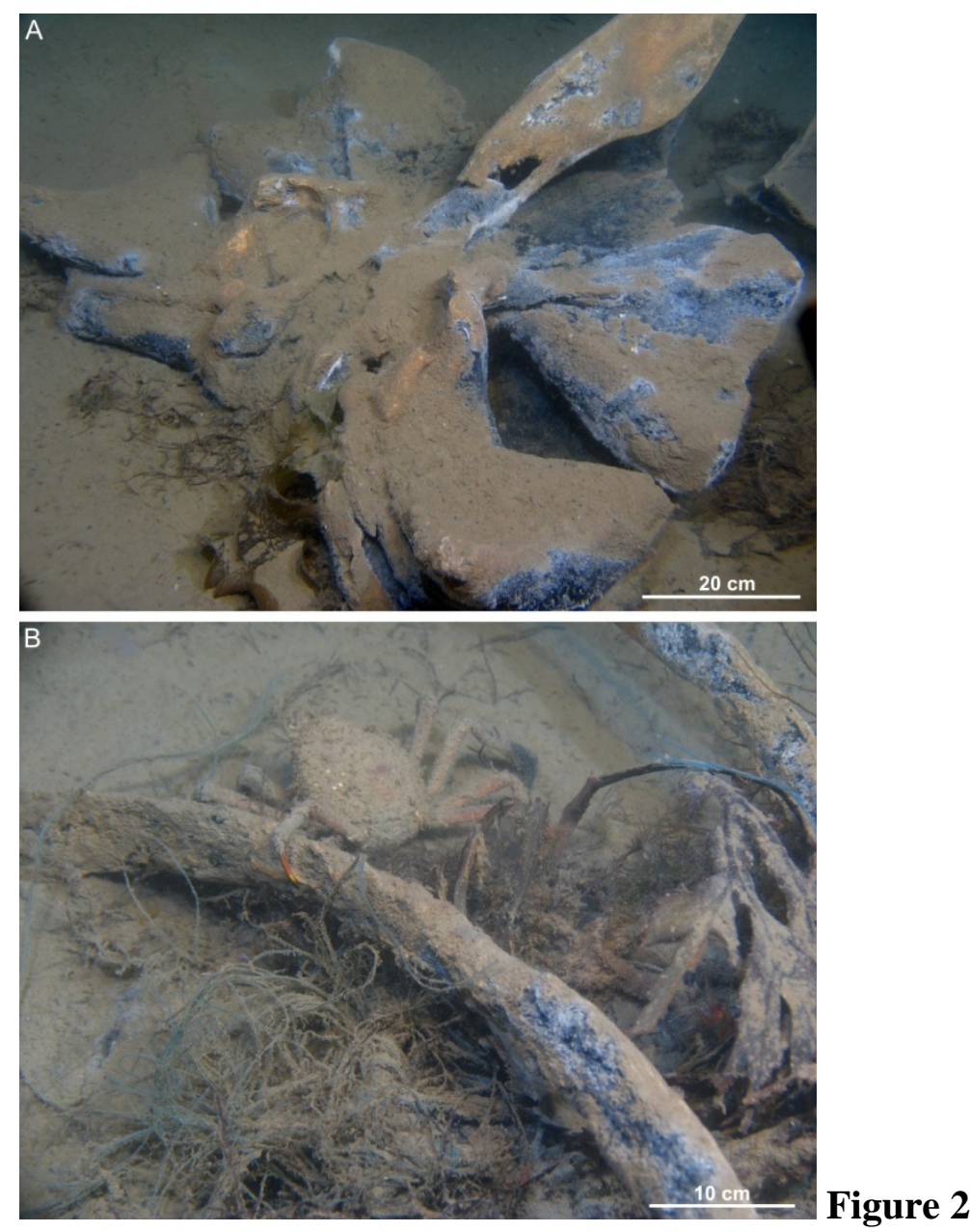


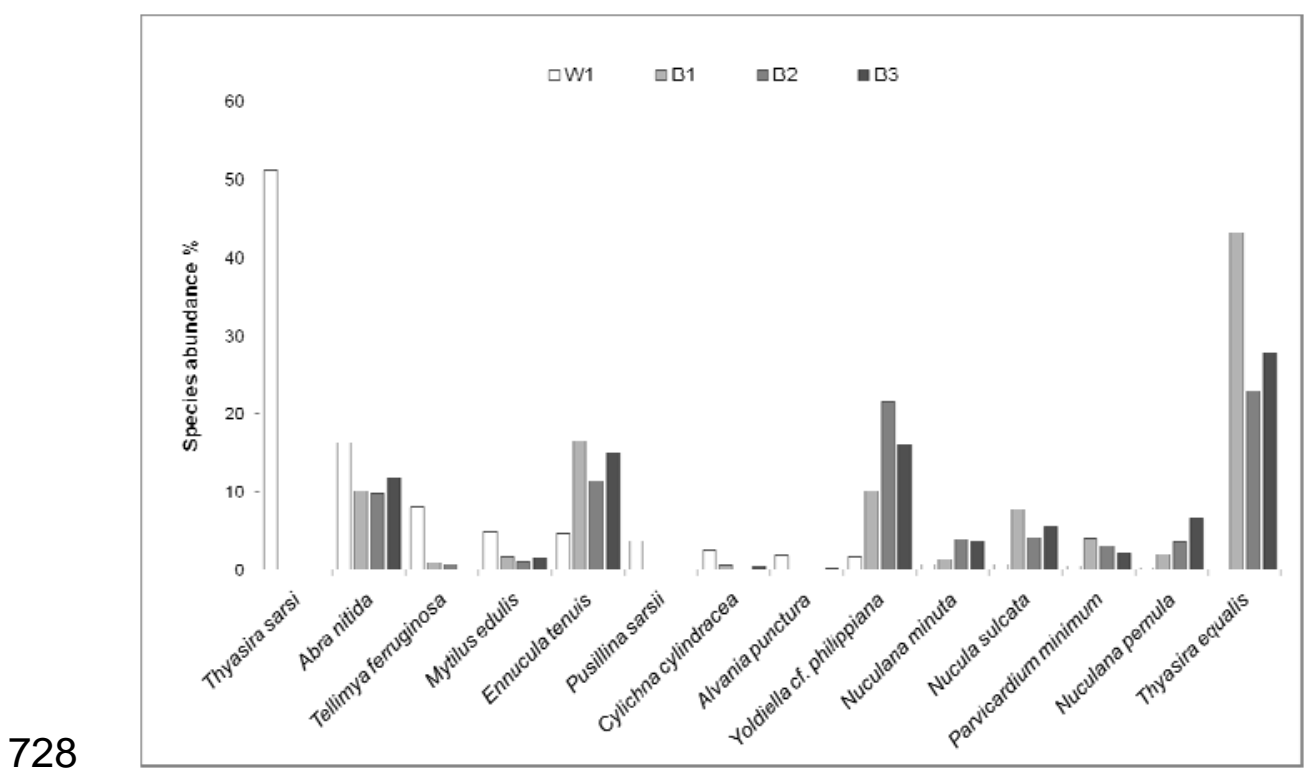

Figure 3
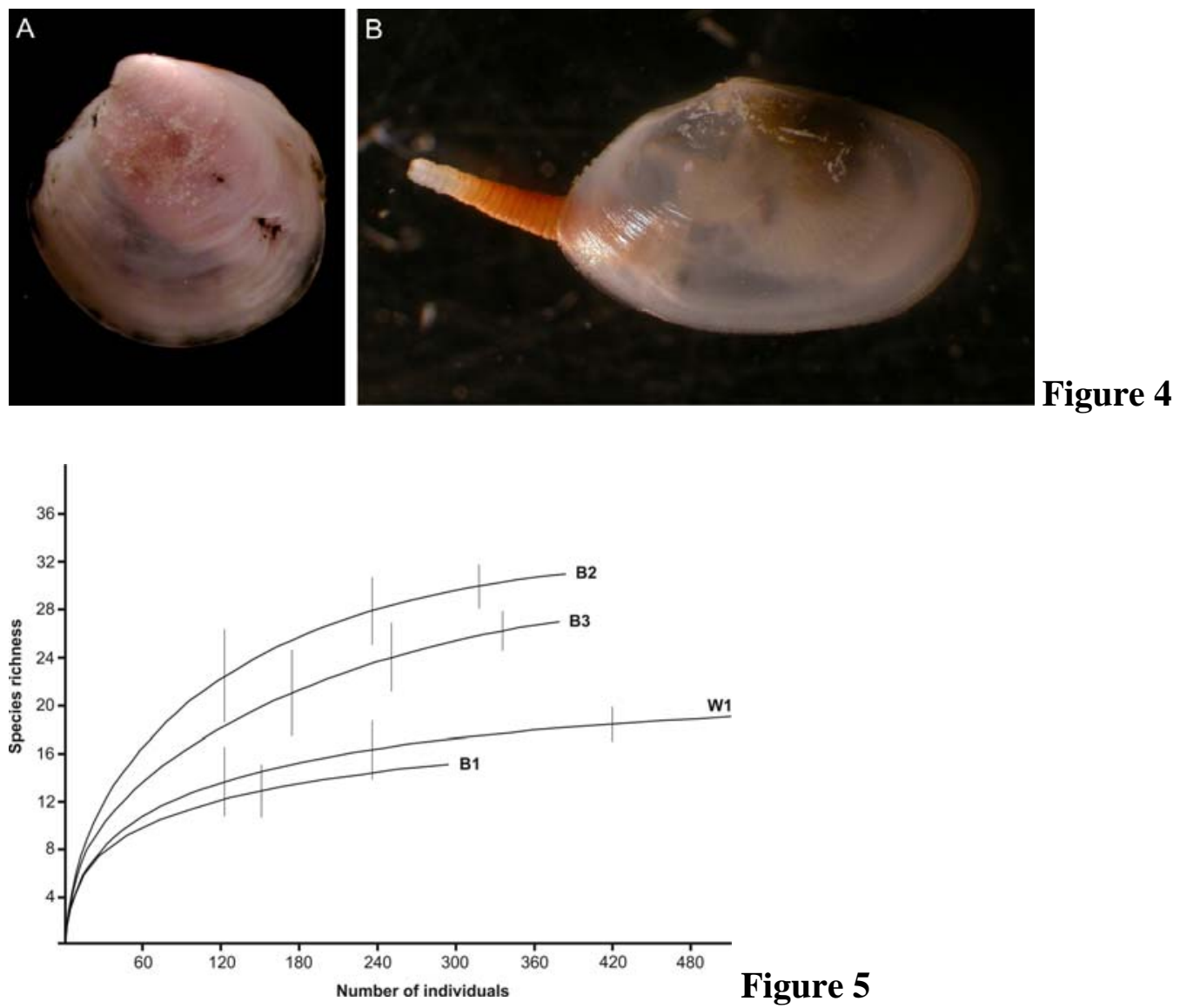


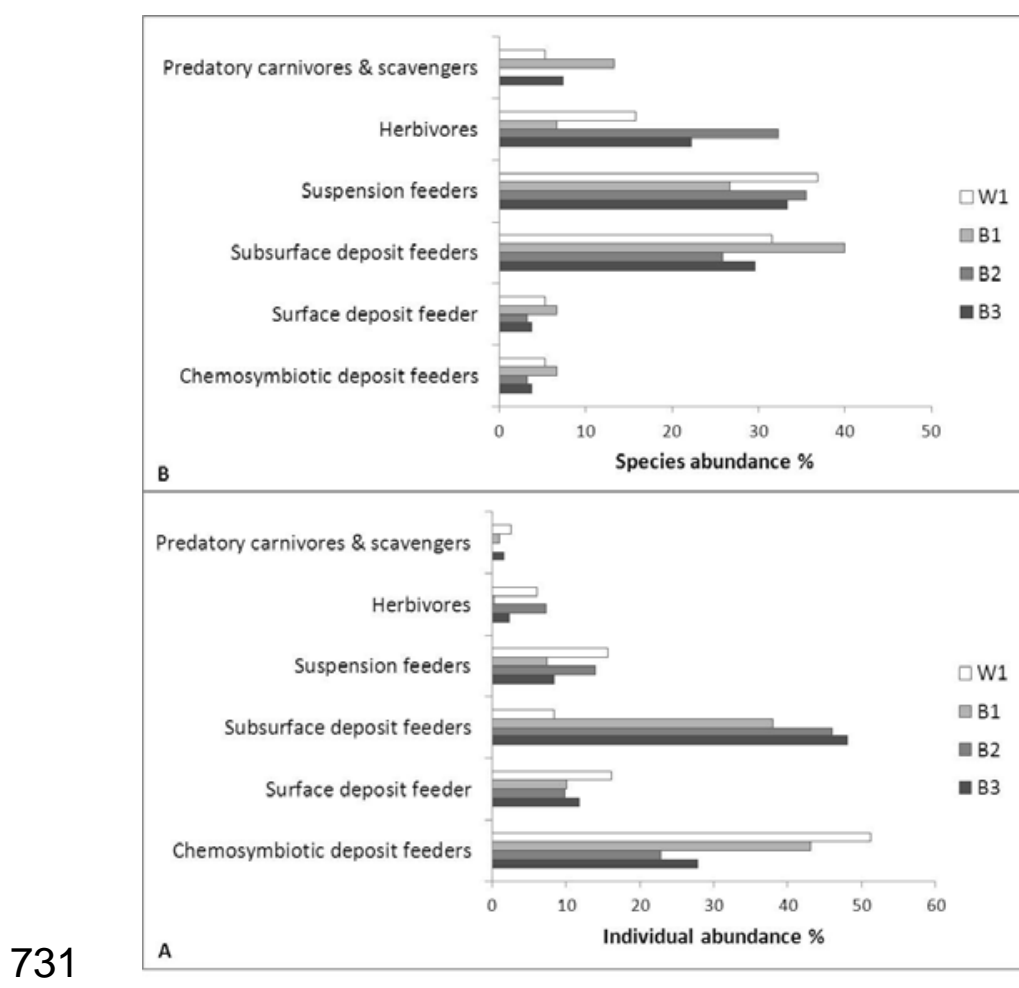

Figure 6

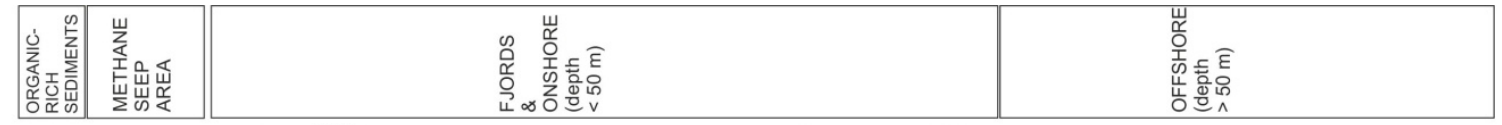

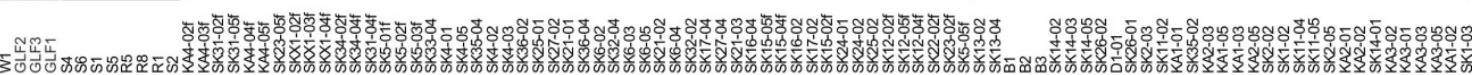

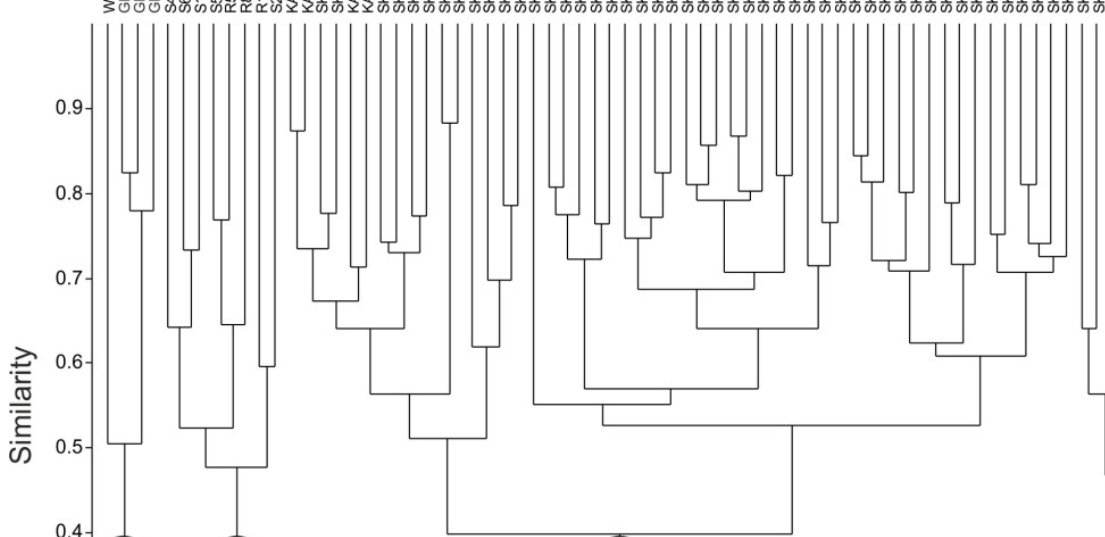

(1) (3) (3)
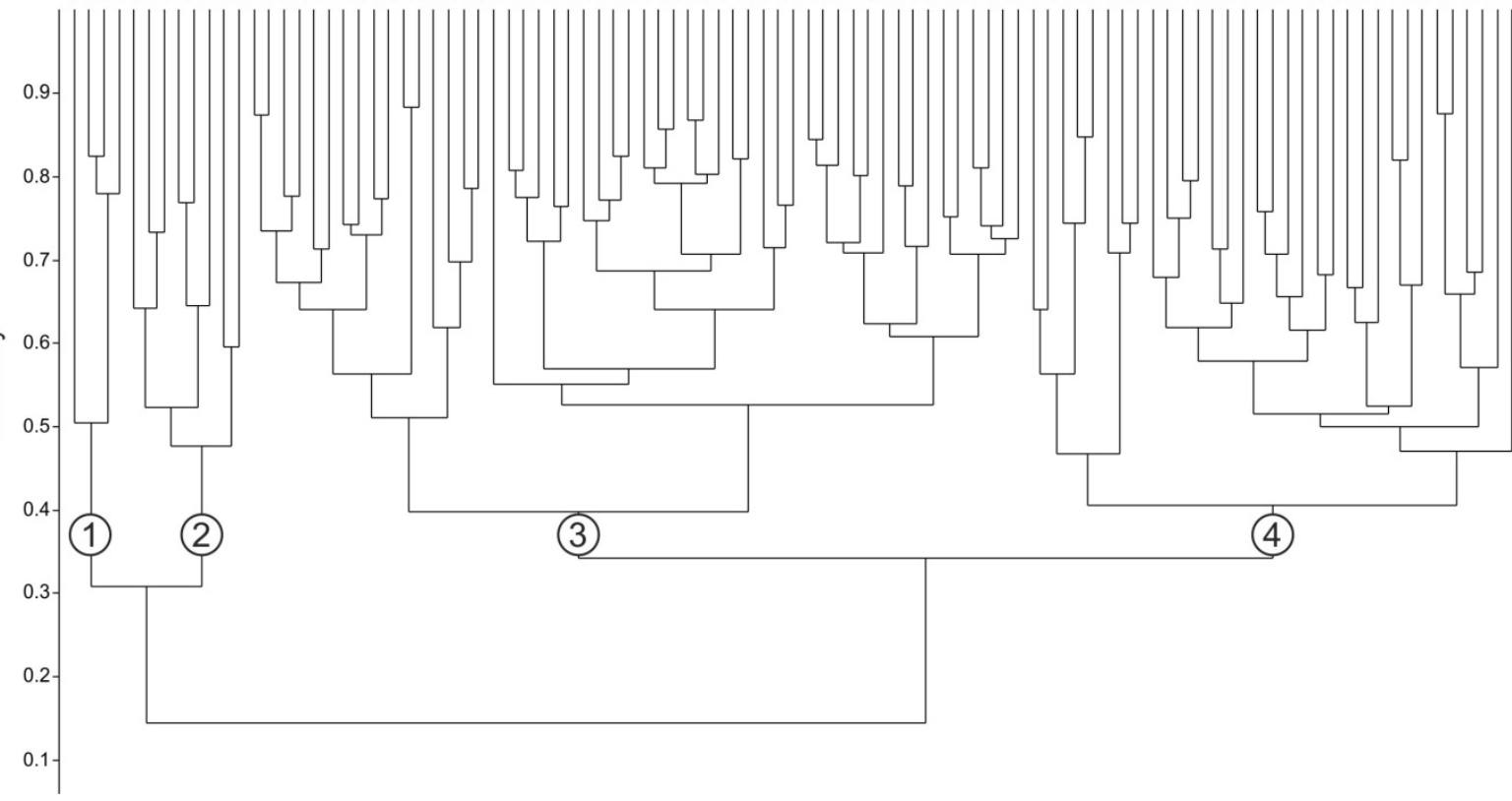

(4)

732

$733 \quad$ Figure 7 


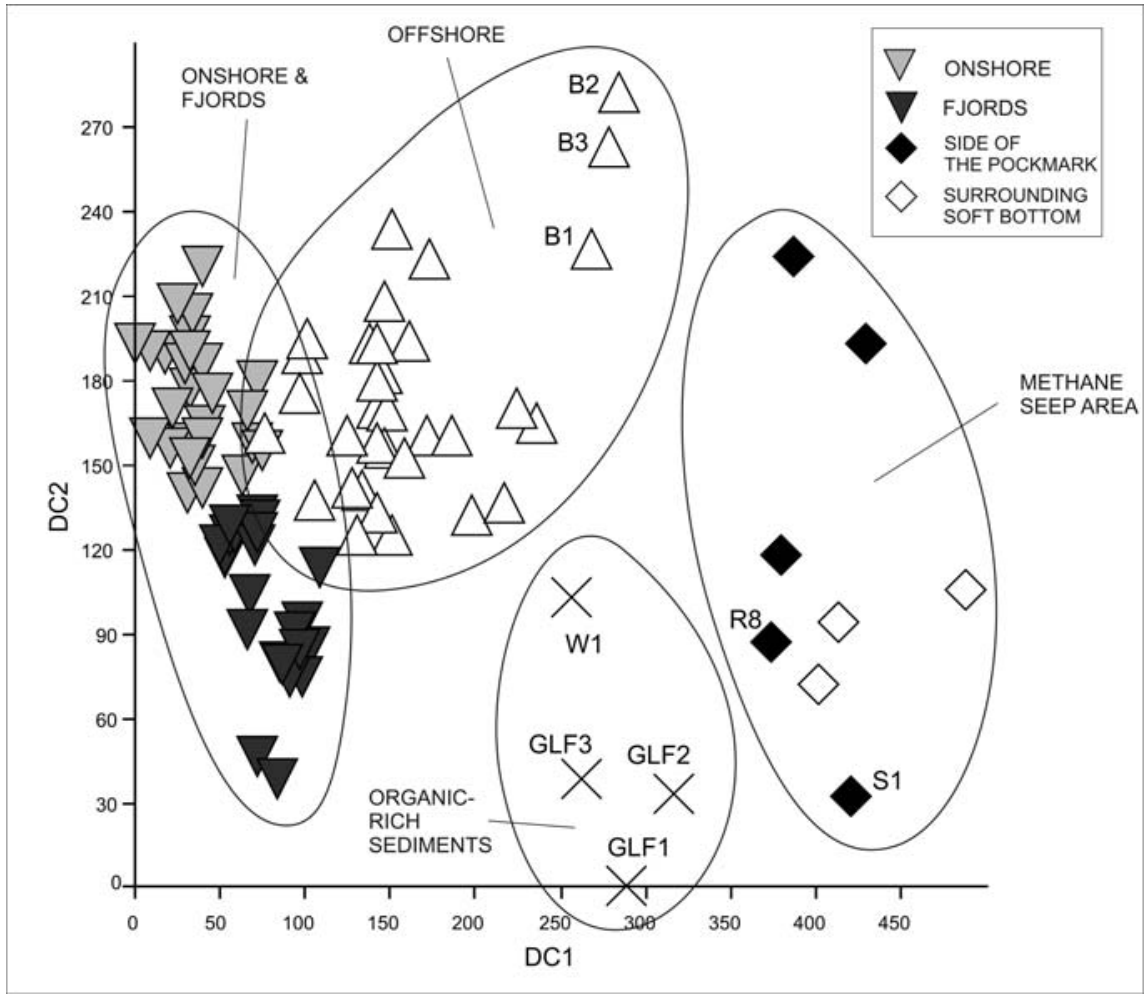

Figure 8

737 TABLES

\begin{tabular}{|c|c|c|c|c|c|c|c|c|}
\hline Sample & Name & Volume & Sampling methods & Depth & Latitude & Longitude & $\begin{array}{l}\text { Distance from } \\
\text { the whale }\end{array}$ & Sampling date \\
\hline & & $\left(\mathrm{cm}^{3}\right)$ & & $(\mathrm{m})$ & $(\mathrm{N})$ & (E) & $(\mathrm{m})$ & \\
\hline Kosterfjord whale fall & W1 & 4420 & ROV scoop & 125 & $58^{\circ} 52,968^{\prime}$ & $11^{\circ} 05,728^{\prime}$ & 0 & May 2008 \\
\hline Kost. backgorund sediments & B1 & 15500 & $0.1 \mathrm{mq}$ Van Veen grab & 125 & $58^{\circ} 52,963^{\prime}$ & $11^{\circ} 05,719^{\prime}$ & 18 & January 2009 \\
\hline Kost. backgorund sediments & B2 & 15500 & $0.1 \mathrm{mq}$ Van Veen grab & 125 & $58^{\circ} 52,973^{\prime}$ & $11^{\circ} 05,725^{\prime}$ & 13 & January 2009 \\
\hline Kost. backgorund sediments & B3 & 15500 & $0.1 \mathrm{mq}$ Van Veen grab & 126 & $58^{\circ} 52,991^{\prime}$ & $11^{\circ} 05,705^{\prime}$ & 55 & January 2009 \\
\hline
\end{tabular}

\section{Table 1}

\begin{tabular}{|c|c|c|c|c|c|}
\hline Sample & $\begin{array}{c}\mathrm{N}^{\circ} \text { of } \\
\text { species }\end{array}$ & $\begin{array}{c}\mathrm{N}^{\circ} \text { of } \\
\text { individuals }\end{array}$ & $\begin{array}{c}\text { Simpson } \\
\text { index of } \\
\text { Dominance } \\
\end{array}$ & $\begin{array}{c}\text { Shannon } \\
\text { index }\end{array}$ & $\begin{array}{c}\text { Fisher's a } \\
\text { index }\end{array}$ \\
\hline & & & (D) & $(\mathrm{H})$ & $(\alpha)$ \\
\hline W1 & 19 & 512 & 0.3022 & 1.755 & 3.887 \\
\hline B1 & 15 & 297 & 0.2421 & 1.828 & 3.332 \\
\hline B2 & 31 & 385 & 0.1297 & 2.516 & 7.947 \\
\hline B3 & 27 & 381 & 0.1495 & 2.297 & 6.638 \\
\hline
\end{tabular}




\begin{tabular}{|c|c|c|c|c|c|}
\hline Species & $\begin{array}{l}\text { Av. } \\
\text { abund. s }\end{array}$ & $\begin{array}{l}\text { Av. } \\
\text { imilarity }\end{array}$ & $\mathrm{Sim} / \mathrm{SD}$ & Contribution & $\underset{\%}{\text { Cumulative }}$ \\
\hline \multicolumn{6}{|c|}{$\begin{array}{l}\text { "Organic-rich sediment" samples } \\
\text { Average similarity }=64.89\end{array}$} \\
\hline Thyasira sarsi & 6.83 & 30.26 & 7.47 & 46.63 & 46.63 \\
\hline Abra nitida & 4.67 & 19.52 & 4.19 & 30.08 & 76.72 \\
\hline \multicolumn{6}{|c|}{$\begin{array}{l}\text { "Onshore" samples } \\
\text { Average similarity = } 60.38\end{array}$} \\
\hline Kurtiella bidentata & 7.31 & 30.04 & 3.18 & 49.76 & 49.76 \\
\hline Hyala vitrea & 4.43 & 15.09 & 1.61 & 25 & 74.75 \\
\hline Varicorbula gibba & 1.5 & 4.27 & 1.3 & 7.07 & 81.83 \\
\hline Abra nitida & 1.75 & 4 & 1.02 & 6.63 & 88.46 \\
\hline \multicolumn{6}{|c|}{$\begin{array}{l}\text { "Fjord" samples } \\
\text { Average similarity = } 57.38\end{array}$} \\
\hline Abra nitida & 5.94 & 19.59 & 2.9 & 34.14 & 34.14 \\
\hline Kurtiella bidentata & 3.96 & 8.99 & 1.11 & 15.67 & 49.81 \\
\hline Nucula nitidosa & 2.21 & 6.41 & 2.77 & 11.18 & 60.99 \\
\hline Hyala vitrea & 2.65 & 6.37 & 1.48 & 11.1 & 72.09 \\
\hline Thyasira flexuosa & 2.15 & 6.14 & 1.82 & 10.7 & 82.79 \\
\hline Varicorbula gibba & 1.26 & 3.01 & 1.3 & 5.24 & 88.03 \\
\hline \multicolumn{6}{|c|}{$\begin{array}{l}\text { "Offshore" samples } \\
\text { Average similarity =48.91 }\end{array}$} \\
\hline Abra nitida & 4.45 & 12.49 & 2.26 & 25.53 & 25.53 \\
\hline Ennucula tenuis & 3.43 & 8.44 & 1.98 & 17.25 & 42.78 \\
\hline Hyala vitrea & 2.63 & 5.67 & 1.16 & 11.59 & 54.38 \\
\hline Thyasira equalis & 2.56 & 5.34 & 1.3 & 10.92 & 65.29 \\
\hline Tellymia tenella & 1.79 & 3.72 & 1.03 & 7.61 & 72.9 \\
\hline Parvicardium minimum & 1.76 & 3.7 & 1.09 & 7.56 & 80.46 \\
\hline \multicolumn{6}{|c|}{$\begin{array}{l}\text { "Methane seep area" samples } \\
\text { Average similarity }=48.91\end{array}$} \\
\hline Thyasira equalis & 6.16 & 25.82 & 2.87 & 47.9 & 47.9 \\
\hline Thyasira obsoleta & 4.44 & 15.06 & 1.52 & 27.94 & 75.84 \\
\hline
\end{tabular}

